\title{
Soft rot disease in Jordan: A Review
}

\section{Ibtihal Mohammad Abu-Obeid}

National Agricultural Research Center (NARC), Plant Protection Directorate. P. O. Box, 693 Baqa' 19381. Jordan

Correspondence Author: Dr. Ibtihal Abu-Obeid, National Agricultural Research Center (NARC), Plant Protection Directorate, P. 0. Box, 693 Baqa' 19381. Jordan.

E-mail: ibtihal@narc.gov.jo

Received date: 15 April 2019, Accepted date: 25 June 2019, Online date: 29 June 2019

Copyright: (C 2019 Dr. Ibtihal Abu-Obeid., This is an open-access article distributed under the terms of the Creative Commons Attribution License, which permits unrestricted use, distribution, and reproduction in any medium, provided the original author and source are credited.

\begin{abstract}
Bacterial soft rot is one of the most destructive diseases of vegetables that occur in Jordan and in many regions of the world. It infects vegetables in the field, during transit and in storage causing great losses depending on the crop and prevailing of favorable conditions of high humidity coupled with high temperature. Generally, various bacterial species are known to be agents causing soft rot, in Jordan it was mainly caused by the pectolytic Pectobacterium carotovorum subsp. carotovorum in addition to Pseudomonas fluorescens, and different Enterobacteriaceae genera such as Enterobacter spp., Serratia spp., and Klebsiella spp., the disease was recorded in all vegetable growing regions and during different growing seasons, with a wide host range infecting many vegetable species belonging to all families causing decay of fleshy tissues. On the other hand, Pectobacterium carotovorum subsp. atroseptecum was found to have a restricted host range of potato and was reported in cool temperate regions or early in the season where the cool temperature is prevailing in potato growing regions. The detection and identification was done by different traditional methods of biochemical and physiological tests in addition to molecular techniques such as amplification of different regions by using different sets of primers.

The bacterium enters the host tissues through natural opening, injures; caused by biotic and abiotic causal agents such as insects or by wrong practices during harvesting causing decay of tissues due to pectolic enzymes secreted by the bacterium, the tissues become soft and slimy where this is the same appearance on most of hosts. Control of the disease includes more effective and sustainable bacterial disease control strategies by applying different measures that reduce wounds and store vegetables in clean stores with low humidity and cold temperature and other physical and chemical methods which is discussed in more details. This review illustrates and discusses the disease status in Jordan through presenting an overview of all the results of studies done on this disease over many years.
\end{abstract}

Keywords: Soft rot, Vegetables, Pectobacterium carotovorum subsp. carotovorum, Jordan

\section{INTRODUCTION}

Although Jordan is a relatively small country, it produces a wide range of vegetables all over the year with different seasons, due to the unique climate of the country. Whereas, high percentages of these vegetables are produced during spring, summer where the production is concentrated in the highlands, while during late fall, winter and early spring production is located in the Jordan Valley. Therefore, the continuous supply of locally produced fresh vegetables is throughout the whole year.

The major vegetable crops that are grown in Jordan; Tomatoes, cucumber, potatoes, pepper, eggplant, cabbage, lettuce, cauliflower, squash...etc. Tomatoes dominate within this group followed by potato, sweet melon, eggplant, cucumber, squash, sugar melon, cauliflower, onions, cabbage, pepper, beans, carrots and spinach. All these crops are grown in the open field (except cucumber, tomatoes and pepper which are completely (cucumber) or partially (tomato and pepper) produced under a plastic cover. In the year 2017, the total number of plastic houses were 140825, with a total production of 856061 ton [5].

Also, during the year 2017; the area planted with vegetables in Jordan was 896426 dunums with a total production of 4575153 ton [5]. Most of the Jordanian vegetable production is consumed locally, either fresh or processed. Also, a considerable part of this production is exported to neighboring countries or Europe.

Plant diseases attack all crops which are considered as the main source for human food all over the world and considered among the main factors that drastically affect its production, resulting in economic losses either in the field or in storage by 
decreasing crop production quality and quantity. Thus, one of the methods to increase food production is to control plant diseases using different control measures by integrated crop management. Plant bacterial diseases attack vegetables and spread in tropical and subtropical regions [11]. Recently the interests in bacterial diseases and its detection and identification have been increased due to its importance and its serious damage on different crops resulting in great losses.

Soft rot is one of the destructive diseases of vegetables prevalent in our region and it is found worldwide wherever fleshy storage tissues of vegetables are found. The disease was detected and reported in Jordan on different vegetable crops either in the field or during transit and in storage or the market, causing a great economic loss.

The infection of this disease leads to greater total loss of products than any other bacterial disease, the amount of economic losses varies according to the crop value and disease severity which is influenced by the growing and storage conditions, losses were estimated to vary between $15-30 \%$ of the harvested crop [1]. It is considered among the factors contributing to yield losses and among the most prevalent and destructive bacterial diseases that affect vegetables and is difficult to control [6]. Many vegetable crops were harvested and coming from the field may already infect but do not show any typical symptoms, but later on with the availability of favourable environmental conditions; high atmospheric temperature, humidity and poor storage and transit conditions, symptoms appear, and infection disseminates.

Many bacterial genera have been reported to cause soft rot such as various species of Bacillus spp., fluorescent Pseudomonas spp., Enterobacter cloacae and Erwinia spp. [7, 1, and 17]. However, Erwinia carotovora subsp. carotovora is considered as the most common and main causal agent for bacterial soft rot of commercially important crops in the warm climatic region of Jordan. While Erwinia carotovora subsp. atroseptica the causal agent of black leg disease was found to be prevalent in cool regions and is restricted to potato, causing blackleg disease in winter in the Jordan Valley region and early spring in the uplands [2-4].

The soft rot bacterium enters plant tissues through wounds, stomata or hydathodes where cultivation, harvesting, handling, freezing or insect injuries are often common points of initial infection. The pathogen is generally spread by irrigation water, rain, several species of maggot flies and other insects. Once the bacterium enters the plant tissues, it produces pectolytic enzymes which break down the pectic substances of the middle lamella, causing maceration of tissues. Soft rot disease caused by Erwinia carotovora subsp. carotovora, which recently known as Pectobacterium carotovorum subsp. carotovorum (Pcc) (Dye, 1969) is listed among the top ten plant pathogenic bacteria [15]. In this review, an effort has been made to overview the status of vegetable soft rot disease in Jordan and presents the results of many studies and surveys which have been done concerning this disease through many years.

\section{CAUSAL AGENTS}

In Jordan Erwinia carotovora subsp. carotovora, which is recently known as $P c c$, was identified as the main causal agent of soft rot disease of vegetables using traditional techniques and later on molecular techniques using amplification of certain regions followed by cloning and sequencing confirmed it in addition to some genera of Enterobacteriaceae.

Recently bacteria belonging to the genus Erwinia were grouped into the genus Pectobacterium and Dickeya and the main virulence determination of these genera are the types of pectolytic enzymes [14]. There are two species: P. carotovorum and D. chrysanthemi that are particularly damaging to potato worldwide, the former is a major pathogen in temperate regions while the other is more damaging in warmer ones. Pectobacterium carotovorum has been divided into five subspecies; atrosepticum, betavasculorum, carotovorum, odoriferum and wasabiae, based on biochemical, physiological and pathogenicity characteristics [12]. Two subspecies in Jordan; carotovorum and atrosepticum are able to cause symptoms on potato both during the vegetative growth of the crop and during storage Whereas, P.c. subsp. atrosepticum thought to be a serious disease in cool temperate regions or early in the season where the cool temperature is prevailing in potato growing regions [11]. On the other hand $P$. $c$. subsp. carotovorum is spread on warmer regions and attacks many other types of vegetables in addition to potato [16, 2].

The detection and identification of soft rot causal agents were carried out through traditional techniques such as isolation on selective media and biochemical and physical characterization.

The isolation of bacteria from diseased samples on Logan's media developed small circular bacterial colonies with pink to red-purple centers confirms that the isolated bacterium is suspected to be Pcc [9].

The results of the reactions of the obtained bacterial isolates from rotted samples against the different biochemical and physiological were found to be oxidase negative, catalase-positive, fermentation of glucose positive rotting induced on inoculated potato slices, urease enzyme produced, growth developed on nutrient agar plates incubated at $37 \pm 2{ }^{\circ} \mathrm{C}$ and on $5 \% \mathrm{NaCl}$. Also all isolates were able to oxidize the alcoholic sugar, discharge it in the media to acidic reaction, $\mathrm{H}_{2} \mathrm{~S}$ was developed in the inoculated test tubes of broth containing cysteine; indole was not produced from tryptophane, nitrite was produced from nitrate, methyl red test positive, acidic reaction with crude formation in litmus milk, starch hydrolysis and sucrose negative and were not able to reduce substances from sucrose. The hypersensitive reaction was developed on tobacco leaves (white burley) injected with suspensions of tested bacterial isolates.

The reactions of the tested bacterial isolates to the different biochemical, physiological and nutritional tests were identical to the results of the same tests ran against the bacterial reference culture of Pcc isolate NCPPB312 [16, 2].

The number of species and subspecies of Pectobacterium has been increased over recent years and, as a result, their identification and differentiation by classical microbiological tests have become challenging. It has been become more challenging to make accurate identification based on biochemical tests alone because phenotypic characteristics vary among strains of the same species and subspecies [8]. However, identification of Jordanian potato soft rot isolates using traditional methods; biochemical and physiological tests only indicated that Pcc was the causal agent of the disease, but later on, using molecular 
techniques such as DNA sequence analysis indicated that these tests were not highly accurate and identified other causal agents, where biochemical tests were able to identify most isolates but misidentified other [2].

Sequence analysis identified in addition to Pcc other bacterial genera that could be associated with soft rot. In 2017, AbuObeid et al., [2] indicated different bacterial causal agents that were associated with Pcc and causing rot diseases such as Pseudomonas fluorescens, different Enterobacteriaceae genera such as Enterobacter spp., Serratia spp., and Klebsiella spp.

\section{DISTRIBUTION}

Generally, the occurrence of different diseases depends on the climate conditions and geographical areas prevailing. Since Jordan is divided into different geographical areas; Jordan Valley, Jordan Valley rift, mountains or uplands and deserts where the environmental conditions of these areas vary according to the season and location. In summer, it is very hot and dry in the desert, hot and dry in Jordan Valley, while it is warm and relatively humid in the uplands and mountains. In winter, it is warm and humid in Jordan Valley, cold and dry in the desert, at the same time cool and humid in the uplands. These wide climatic variations in Jordan permit planting vegetables throughout the whole year and illustrate the importance of different plant bacterial diseases in relation to occurrence, development and spreading, as well as, under certain conditions could lead to an epidemic bacterial disease [11].

Bacterial soft rot incited by Pcc has the broadest geographic distribution; it occurs worldwide and causes serious diseases of vegetable crops in the field, storage and during transit. It infects crops mainly in tropical and subtropical regions causing greater loss of produce than any other bacterial disease [1].

Approximately, all growing regions planted with different vegetables have been inspected by field trips to all vegetable growing areas during all seasons at different plant growth stages. The results indicated the occurrence and spreading of soft rot bacterial diseases in the different inspected agricultural areas throughout the country, it occurred in all surveyed areas including Jordan Valley and the Uplands: Amman, Jerash, AR Ramtha, Ma'an, Madaba and Mafraq, in the field and storage and in all growing seasons $[17,2]$.

\section{HOST RANGE}

Soft rot disease caused by $P$. carotovorum subsp. carotovorum (Pcc) (Dye, 1969) is listed among the top ten plant pathogenic bacteria [16] with a wide host range in tropical and subtropical regions infecting vegetable species belonging to different major vegetable families. In Jordan it was isolated from naturally infected parts of the following hosts: Artichoke (Helianthus tuberosus) Banana (Musa acuminate) Bean (Phaseolus vulgaris) Beet (Beta vulgaris) Cabbage (Brassica Oleaceae var. capitata) Cauliflower (Brassica olearaceae var. botrytis) Carrot (Dacus carota), Celery (Apium graveolens ) Chard (Beta vulgaris var. cicla) Chinese cabbage (Brassica chinensis) Eggplant (Solanum melongena) Garlic (Allium sativum ) Lettuce (Lactuca sativa) Marrow (Cucurbita pepo) Onion (Allium cepa) Parsley (Petroselnium crispum) Pea (Pisum sativum ) Pepper (Capsicum frutescens ) Pomegranate (Punica granatum ) Potato (Solanum tuberosum) Tomato (Lycopersicon esculentum ) Pumpkin (Cucurbita maxima) Radish (Raphanus sativus ) Spinach (Spinacia olearaceae) Sweet melon (Cucumis melo) Watermelon (Citrullus fanatus) Gladiolus (Gladiolus communis) Cucumber (Cucumis sativus ) Common mallow (Malva sylvestris) in addition to Dieffenbachia (Dieffenbachia maculate) $[17,11]$.

On the other hand, black leg disease Pectobacterium carotovorum subsp. atroseptecum is restricted to potatoes (Solanum tuberosum) [11].

\section{SEVERITY OF SOFT ROT}

There are no accurate studies and measurements for the severity of soft rot disease infecting vegetables in Jordan. In common, the loss caused by soft rot bacteria could be great depending on the crop, season and stage of infection and depending on climate, condition of growth and storage conditions [16].

It causes rotting in both field and during storage under favourable environmental conditions of wet and warm soils and in the presence of film of water, warm and anaerobic storage conditions. A study done by Rajeh and Khlaif [17] they found that soft rot of potatoes is a seed-borne disease where the contaminated mother tubers were reported to be the main source of inoculums in Jordan. Under Jordan Valley conditions the fluctuation in the recovered population of Pcc trend was found to be coincided with the fluctuation in soil temperature where the highest population was found to be favoured with average temperature of $25{ }^{\circ} \mathrm{C}$ during April and May, while the lowest population was found at average temperature of $38.8{ }^{\circ} \mathrm{C}$ during August and September [17].

Also, different potato cultivars grown in Jordan varied in their susceptibility to soft rot bacterium, where Ajax was found to be the least susceptible, while Spunta was the most susceptible one [18]. Also, some cultivars varied in their response to different soft rot bacterial isolates.

On the other hand, the relationship of potato bacterial soft rot disease with a reduced sugar content of potato was studied by Khlaif and Wreikat [10]. The study was conducted to test the susceptibility of 5 different potato cultivars to the artificial inoculation with $10^{7} \mathrm{Cfu} / \mathrm{ml}$ of the suspension of the causal agent Pectobacterium carotovorum subspecies carotovorum and the relationship of their susceptibility to reducing sugar and calcium contents of the tested potato cultivars tubers. The results of the study showed that all the tested potato cultivars were found to be susceptible to the artificial inoculation of the disease where Spunta was found to be the most susceptible cultivar, while Ajax was the lowest one. At the same time, a positive correlation was 
found between the reducing sugar content of the tested potato cultivars tubers and the susceptibility to soft rot. Specifically, Spunta, the highest susceptible one, was found to have the highest reducing sugar content, in the meantime, Ajax the lowest susceptible one had the lowest reducing sugar content. On the other hand, a negative correlation was found about calcium peel content, where the results showed that Spunta the highest susceptible one had with the lowest calcium content and Ajax the lowest susceptible one had the highest calcium content [10].

\section{SYMPTOMS}

Soft rot disease caused by $P c c$ bacteria enters the plants through wounds caused by insects, hail, and farmer practices such as pruning or harvesting methods also through lenticels and another natural opening. Soft rot symptoms are similar on most plants; the disease starts on leaves, stems and underground parts as small water-soaked lesion which enlarges rapidly due to the secretion of pectolic enzymes which break down middle lamella of tissues causing the inner contents of the cell to fuse out. Infected tissues become soft and slimy without much discoloration; the rotted area is separated from a healthy one by dark brown or black borders. In the early stages rotting tissue is usually odorless, later on it develops foul odor as secondary organisms invade the rotted tissue $[1,6,13]$. In potato the infected mother tubers break down in the soil releasing huge numbers of bacteria that can infect daughter tubers via wounds or through lenticels especially in wet soils. However, symptoms on leafy crops such as crucifers, lettuce spinach and onion turn into watery green, slimy masses give off a bad odor within a short time at room temperatures or when stored at favorable conditions of warm and humid storage conditions

When fleshy roots, rhizomes, tubers corms of some vegetables such as carrot, turnip infected in the field, the first symptoms of the disease in plants are poor shoot growth and yellowing of the leaves. Small, water-soaked lesions appear on tubers and the stem bases. If conditions favor disease development (warm and wet), the lesions rapidly enlarge resulting in a soft decay. The rot often begins at the outside of the bases of leaf petioles below the soil line, and may spread inwards some distance through stems before leaves begin to yellow. Rots may progress up stems, causing blighting of leaves, and may also progress down into tubers. The roots can be infected, becoming transparent and slimy before decaying completely. In some conditions, the decay of tubers can be white to creamy in colour. When tubers are infected, the foliage attached to their affected parts rapidly wilts, yellows, and topples over. Infected flower stems behave the same way. When tubers are completely rotted, entire plants completely collapse and rot. Rotted tubers are usually reduced to a whitish, mushy, foul-smelling pulp surrounded, in most instances, by loose skin, which has more resistance to decomposition [1].

\section{CONTROLLING MEASURES}

Generally, control of bacterial diseases depends on accurate detection and identification of the causal agent. Although the diagnosis of bacterial diseases depending on symptoms is simple, but symptoms are not always specific and can be confused with other factors either biotic or abiotic [11]. On the other hand, for preventive control measures detection of the causal agent in symptomless plant material is necessary but can be difficult, because the pathogen may be present in the low population and the uneven distribution in the infected plants [16].

However, the diagnosis of the disease is not always related to field inspection, so it is important to detect the pathogen in different plant parts or seeds or even transplants before distributing to farmers to reduce or suppress the spreading of the disease. Efficient detection and identification methods with low costs are essential to investigate the ecology and pathogenesis of soft rot causal agents as well as in seed certification programs [2].

Several measures must be taken in consideration to prevent or at least decrease the infection level of soft rot diseases, from which; it is essential to plant only certified and disease-free plant parts and destroy infected and rotted bulbs, corms, rhizomes, tubers, roots or any infected parts properly. Planting should be in well-drained, fertile soil, good air circulation, avoiding excessive nitrogen fertilization which gives green and soft tissues. Use clean sacs or any types of packets to store plant parts and store them in a clean storage house with good ventilation to keep the humidity of air low and cold temperature $4-6{ }^{\circ} \mathrm{C}$.

In case we have a contaminated field, crop rotation should be applied with crops not host for the disease such as corn or cereals in addition to applying insecticides before planting in order to control insects that commonly cause wounds and play role in dissemination of the bacterial cells such as borers, grubs, wireworms, maggot, flies, beetles and other insects [1].

Avoid wounding during cultivation, digging, handlings during and after harvest packing and storing and it is important to harvest during dry weather.

Currently, the primary methods for controlling postharvest bacterial soft rot are bactericides, such as hypochlorite, formaldehyde solution which are used to kill bacterial cells in addition to antibiotics these chemicals are used as fumigants, sprays to clean stores [6]. However, the continued use of chemical bactericides is limited because of the development of bacterial resistance and growing public concerns over human health and environmental risks over chemical residues.

There are no effective chemical controls for any of soft rot causal agents using a disinfectant such as sodium or calcium hypochlorite as a source of chlorine, which is used to wash crops before shipment or storage as a disinfectant in wash water to reduce the chance of rotting, where chlorination acts as a preventing measure only. If there is already disease decay or injury in the field, the chlorine will help limit the spread of soft rot in storage. Also, the antimicrobial agents such as peroxyacetic acid and hydrogen peroxide which could be applied as a final rinse in packing process are effective in reducing the surface population of soft rot causal agents resulting in less post-harvest loss [6].

Copper bactericides provide some bacterial control when applied before the disease is observed. Sprays should be initiated two weeks before planting and continued on a 5 to 10-day spray interval depending on weather conditions. 
Also, calcium is integral to maintain cell wall rigidity, and it counters the activity of soft rot causal agents' enzymes that degrade cell walls, which is correlated with the susceptibility of certain varieties to soft rot than others [10].

\section{CONCLUSION}

Soft rot disease was detected, identified and recorded on many vegetable crops grown in Jordan, which resulted in high economic loss. Accordingly, the identification of the disease using efficient methods is essential to investigate the ecology of the disease and therefore help in employing the efficient control method. The occurrence of this bacterial disease in different growing areas in Jordan with different environmental conditions could develop new strains, where atypical symptoms could be very difficult to diagnose and control.

This review illustrated all the work that has been done concerning this disease and should act as the base for researchers in this field to take advantage and implement further studies to control soft rot disease.

\section{CONTRIBUTION TO KNOWLEDGE}

Research in plant pathology has made significant contributions to the knowledge of basic biology and genetics of plants and microorganisms as well as to the development of new products for industry. As agriculture struggles to support the rapidly growing global population, plant disease reduces the production and quality and quantity of food, fiber and biofuel crops. Losses are high, on average account for $42 \%$ of the production of the six most important food crops. Losses in the field and storage due to postharvest disease can be disastrous. Farmers spend money, time and effort on disease management, often without adequate technical support, resulting in poor disease control, pollution, and harmful results.

Control of bacterial diseases depends on accurate detection and identification of the causal agent. Although the diagnosis of bacterial diseases depending on symptoms is simple, but symptoms are not always specific and can be confused with other factors either biotic or abiotic. On the other hand, for preventive control measures detection of the causal agent in symptomless plant material is necessary but can be difficult, because the pathogen may be present in the low population and in the uneven distribution in the infected plants.

Many plant bacterial diseases, from which soft rot diseases were detected, identified and recorded that cause diseases of many crops grown in Jordan, which resulted in high economic loss. Accordingly, the identification of these diseases using efficient methods is essential to investigate the ecology of these diseases and therefore help in employing the efficient control method.

\section{CONFLICT OF INTEREST}

The author declares no conflict of interest

\section{REFERENCES}

1. Agrios, George, 2005. Plant Pathology, $\left(5^{\text {th }}\right.$ ed.), London: Elsevier Academic Press.

2. Abu-Obeid, I., Khlaif, H. and Salem, N., 2017. Detection and identification of bacterial soft rot of potato Pectobacterium carotovorum subsp. Carotovorum using specific PCR primers in Jordan. African Journal of Agricultural Research, 12 (39): 2910 - 2918.

3. Al Masa'adeh M, Khlaif H., 2003. Potato blackleg in Jordan: Reaction of some potato cultivars to the infection and effect of planting date. Jordan Journal of Agricultural Science, 30(2):15-20.

4. Al-zomor R, khlaif H, Akash M., 2013. Detection and Identification of Erwinia carotovora subsp. atroseptica (Van Hall, 1992) the causal agent of Potato Black leg by RFLP-PCR. Jordan Journal of Agricultural Sciences, 9(2):170-183.

5. Anonymous, 2017. Ministry of Agriculture Statistical Year Book Jordan.

6. Bhat, K. Masood, N. Bhat, N. Ashraf, B. M. Razvi, S. Mi, M. Akhtar, N. and Habib, M., 2010. Current status of postharvest soft rot in vegetables: A review. Asian Journal of Plant Science, 9(4): 200-208.

7. Bishop, A. L. and Davis, R. M., 1990. Internal decay of onion caused by Enterobacter cloacae. Plant Disease, 74: 692-694.

8. De Boer, S. Li, X. and Ward, L., 2012. Pectobacterium spp. associated with bacterial stem rot syndrome of potato in Canada. Phytopathology, 102 (10):937-947.

9. Fahy, P. and Parsley, G., 1983. Plant Bacterial Diseases. ( $1^{\text {st }}$ ed.), Sydney: Academic Press.

10. Hamid Khlaif, Bilal Wreikat, 2018. The Relationship of Potato Bacterial Soft Rot Disease with Reduced Sugar Content of Potato Tubers and Calcium. Jordan Journal of Agricultural Sciences, 14(1): 81-90.

11. Hamed Khlaif, Ibtihal Abu-Obeid, and Bilal Werikat, 2018. Occurrence of Plant Bacterial Diseases in Jordan. African Journal of Agricultural Research. 13(40): 2104-2117.

12. Hauben, L. Moore, E. Vauterin, L. Steenackers, M. Mergaert, J. Verdonck, L. and Swings, J.,1998. Phylogenetic position of phytopathogens within the Enterobacteriaceae. Systemic Applied Microbiology, 21(3): 384-397.

13. Helias, V. Hamon, P. Huchet, E. Wolf, J. and Andrivon, D., 2012. Two new effective semi selective crystal violet pectate media for isolation of Pectobacterium and Dickeya. Plant Pathology, 61: 339-345.

14. Ma, B., Hibbing, M. E. Kim, H. S. and Reedy, R. M., 2007. Host range and Molecular phylogenies of the soft rot enterobacterial genera Pectobacterium and Dickeya. Phytopathology, 97: 1150-1163. 
15. Mansfield, J. Genin, S. Magori, S. Citovskyi, V. Sriariyanumr, M. Ronald, P. Dow, M. Verdier, V. Beer, S. Machado, M. Toth, I. Salmond, G. and Foster, J., 2012. Top 10 plant pathogenic bacteria in molecular plant pathology. Molecular Plant Pathology, 13: 614-629.

16. Palacio-Bielsa, A., Cambra, M. and Lopez, M., 2009. PCR detection and identification of plant pathogenic bacteria: updated review of protocols (1989-2007). Journal of Plant Pathology, 91 (2): 249-297.

17. Rajeh, O. and Khlaif, H., 2000. Soft rot disease of vegetables in Jordan: host range, reaction of some potato cultivars to the identification and effect of planting date. Dirasat, Agricultural Sciences, 27(2): 149-157.

18. Schroeder, B. K., duToit, L. J. and Schwartz, H. F., 2009. First report of Enterobacter colace causing onion bulb rot in the Colombia Basin Washington state. Plant Disease, 93: 223-228. 